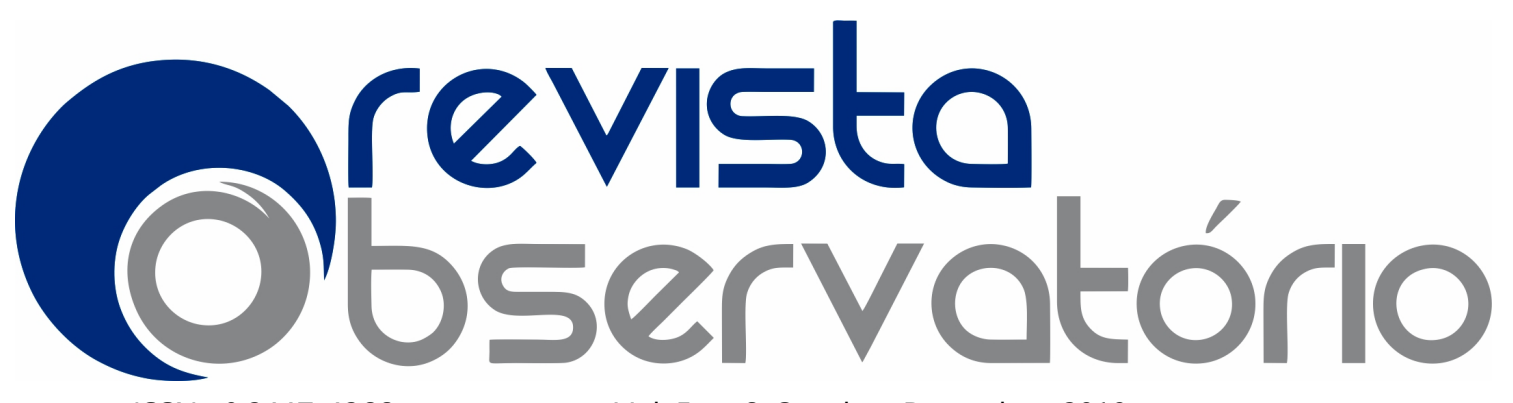

ISSN n² 2447-4266

Vol. 5, n. 6, Outubro-Dezembro. 2019

DOI: http://dx.doi.org/10.20873/uft.2447-4266.2019v5n6p834

\section{AS DIFICULDADES DE \\ LICENCIANDOS COM O \\ USO DE MATERIAIS \\ AUTORAIS DIGITAIS \\ EDUCACIONAIS}

GRADUATION DIFFICULTIES BY USING EDUCATIONAL DIGITAL AUTHORIAL MATERIALS

DIFICULTADES DEL GRADUANDO AL UTILIZAR MATERIALES AUTORALES DIGITALES EDUCATIVOS

Luciana de Lima ${ }^{1}$

\title{
RESUMO
}

O objetivo da pesquisa é analisar quais são as dificuldades que os licenciandos da disciplina Tecnodocência ofertada no primeiro semestre de 2019 apresentam em relação à utilização de Materiais Autorais Digitais Educacionais (MADEs). A pesquisa qualitativa de caráter exploratório, investiga cinco grupos interdisciplinares formados por licenciandos de diferentes áreas do conhecimento. Os dados foram coletados a partir dos roteiros e dos MADEs propriamente ditos. Diante de uma análise interpretativa, constatou-se que os licenciandos, ao utilizarem tecnologia digital, trouxeram o aluno para o centro do processo de ensino, aprendizagem e avaliação; apresentaram dificuldades em relacionar os conteúdos de diferentes áreas de forma interdisciplinar.

\footnotetext{
${ }^{1}$ Licenciada em Matemática pela Universidade Federal do Ceará - UFC (1994), Especialista em Psicopedagogia pela Universidade Estadual Vale do Acaraú - UVA (2003), Especialista em Tecnologia com ênfase em Telemática pelo Centro Federal Tecnológico do Ceará - CEFETCE (2006), Mestre em Educação pela Universidade Estadual do Ceará - UECE (2008) e Doutora em Educação, linha Educação, Currículo e Ensino, eixo Ensino de Ciências, pelo Programa de PósGraduação da Faculdade de Educação da UFC (2014). Atualmente é professora DE Adjunta da Universidade Federal do Ceará, com lotação no Instituto Universidade Virtual (IUVI). E-mail: luciana@virtual.ufc.br.
} 


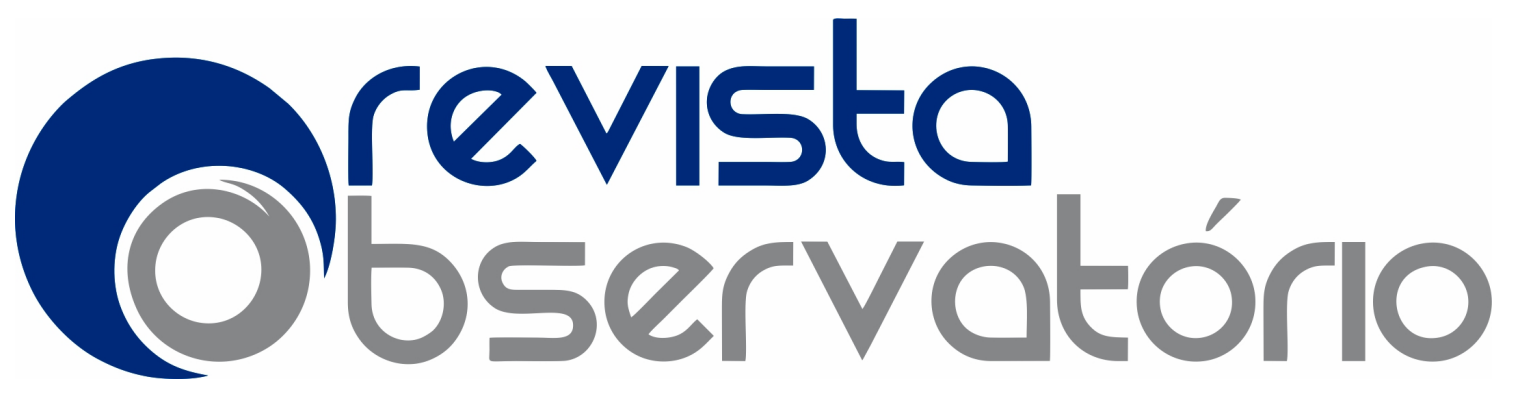

ISSN n² 2447-4266

Vol. 5, n. 6, Outubro-Dezembro. 2019

DOI: http://dx.doi.org/10.20873/uft.2447-4266.2019v5n6p834

PALAVRAS-CHAVE: Licenciatura; Tecnologia Digital; Autoria; Docência.

\begin{abstract}
The objective of the research is to analyze what are the difficulties that the graduates of the Technoteaching discipline offered in the first semester of 2019 present in relation to the use of Educational Digital Authorial Materials (MADEs). The qualitative exploratory research investigates five interdisciplinary groups formed by undergraduates from different areas of knowledge. Data were collected from the scripts and the MADEs themselves. Faced with an interpretative analysis, it was found that the graduates, using digital technology, brought the student to the center of the teaching, learning and evaluation process; presented difficulties in relating the contents of different areas in an interdisciplinary way.
\end{abstract}

KEYWORDS: Graduation; Digital Technology; Authorial; Teaching.

\title{
RESUMEN
}

El objetivo de la investigación es analizar cuáles son las dificultades que los graduandos de la disciplina de Tecnodocencia ofrecieron en el primer semestre de 2019 en relación con el uso de Materiales Autorales Digitales Educativos (MADEs). La investigación cualitativa exploratoria inquiere cinco grupos interdisciplinarios formados por estudiantes universitarios de diferentes áreas del conocimiento. Los datos fueron recolectados de los guiones y de los mismos MADEs. Frente a un análisis interpretativo, se descubrió que los graduandos, utilizando tecnología digital, llevaron al estudiante al centro del proceso de enseñanza, aprendizaje y evaluación; presentaran dificultades para relacionar los contenidos de diferentes áreas de manera interdisciplinaria.

PALABRAS CLAVE: Grado; Tecnología Digital; Autoria; Enseñanza.

Recebido em: 01.06.2019. Aceito em: 09.09.2019. Publicado em: 01.10.2019. 


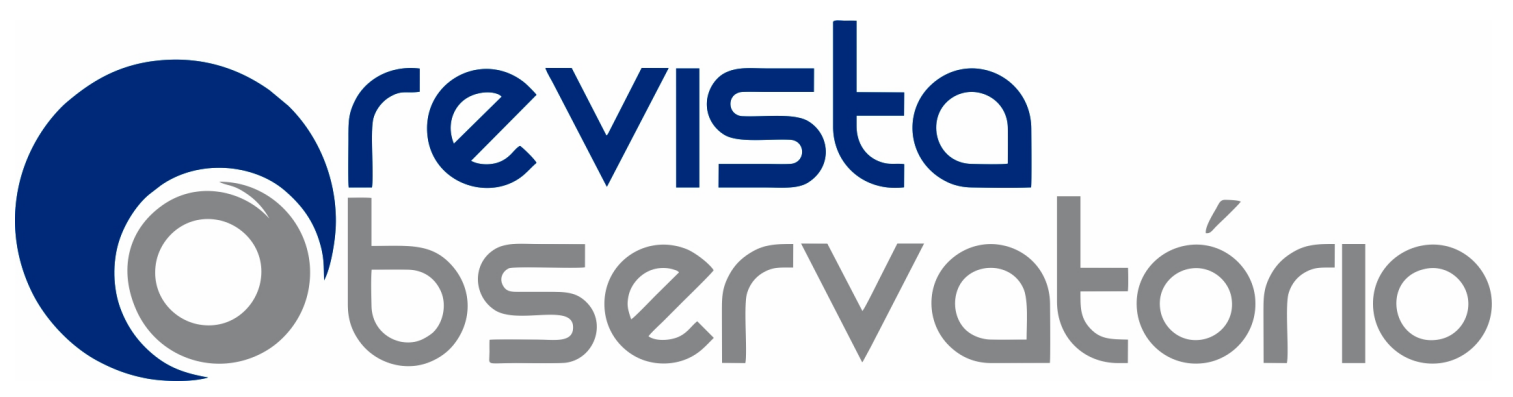

ISSN n² 2447-4266

Vol. 5, n. 6, Outubro-Dezembro. 2019

DOI: http://dx.doi.org/10.20873/uft.2447-4266.2019v5n6p834

\section{Introdução}

Com o advento da tecnologia, a sociedade sofre diversas mudanças ao longo dos anos. Essas mudanças movimentam a economia, as comunicações e os diversos aspectos sociais. A educação é uma das áreas que também é atingida por essa alteração, pois um novo perfil de aluno surgiu. Os alunos não possuem os mesmos interesses e as exigências não são as mesmas de anos anteriores. Por isso, os professores precisam se adaptar às transformações. Esse novo perfil de aluno inclui um grupo que segundo Ceretta e Froemming (2011) estão inseridos na Geração Z.

Esses adolescentes da Geração Z nunca conceberam o mundo sem computador, chats e telefone celular e, em decorrência disso, são menos deslumbrados que os da Geração Y com chips e joysticks. Sua maneira de pensar foi influenciada, desde o berço, pelo mundo complexo e veloz que a tecnologia engendrou. (CERETTA; FROEMMING, 2011, p. 19).

Devido ao contato intenso com as tecnologias digitais, os indivíduos dessa nova geração possuem a habilidade de absorver diversas informações, como também desenvolver atividades de forma simultânea. Os alunos da Geração Z estão em constante interação on-line onde se encontram em seu centro construtivo.

Diante deste perfil, dentro das escolas, um questionamento tem se inserido nas discussões. As aulas tradicionais que são prioritariamente expositivas estão sendo questionadas no que diz respeito à sua eficácia, perante o novo perfil de aluno. Algumas escolas estão incentivando os professores à mudança de suas abordagens pedagógicas e à utilização das tecnologias. Nos cursos de Licenciatura a transformação do ato de "dar aula" também está sendo uma pauta; 


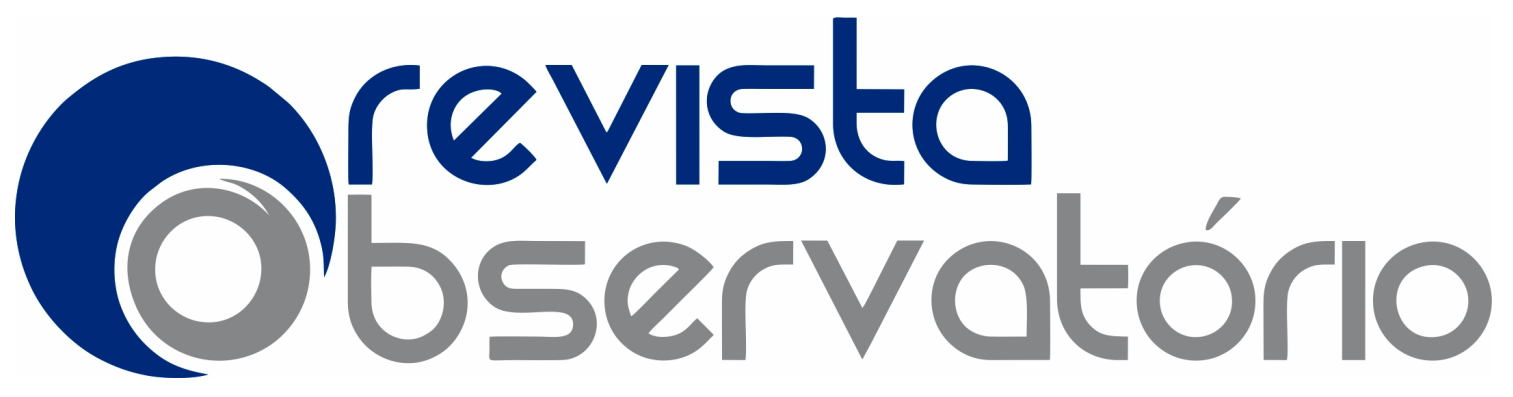

ISSN n² 2447-4266

Vol. 5, n. 6, Outubro-Dezembro. 2019

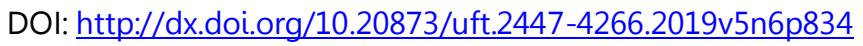

porém, essa busca pela mudança está sendo um problema para muitos licenciandos.

\begin{abstract}
Para nós, professores, essa mudança de atitude não é fácil. Estamos acostumados e sentirmo-nos seguros com o nosso papel de comunicar e transmitir algo que conhecemos muito bem. Sair dessa posição, entrar em diálogo direto com os alunos, correr risco de ouvir uma pergunta para a qual no momento talvez não tenhamos resposta, e propor aos alunos que pesquisemos juntos para buscarmos resposta - tudo isso gera um grande desconforto e uma grande insegurança. (MASETTO; BEHRENS, 2000, p. 142).
\end{abstract}

Os licenciandos possuem como modelo as aulas expositivas que são disseminadas há muito tempo na educação brasileira, que estão se tornando menos atrativas e podem, em alguns casos, não serem eficazes para esse "novo aluno", pois nas aulas expositivas o aluno é apenas o receptor e não o desenvolvedor e coautor do processo de aprendizagem. Essa metodologia incentiva o mito de que o professor é o repassador de conhecimentos, e como reflete Freire (1996), docência e discência são interdependentes, pois as duas são sujeitos e não objeto uma da outra.

O conceito de Materiais Autorais Digitais Educacionais (MADEs) surgiu recentemente com $\mathrm{O}$ intuito de auxiliar $\mathrm{O}$ processo de mudança do perfil tradicional de aula. Os MADEs são materiais que derivados de uma linguagem binária (1 e 0), podem ser visuais, audiovisuais, aplicativos on-line e off-line, trazendo uma perspectiva interdisciplinar, que visa fazer com que dois conhecimentos se unam diante da explicação de um único objeto (LIMA; LOUREIRO, 2019).

Os MADEs estão imbricados em uma perspectiva construcionista, uma teoria desenvolvida por Papert (2008), visando a construção e experimentação da 


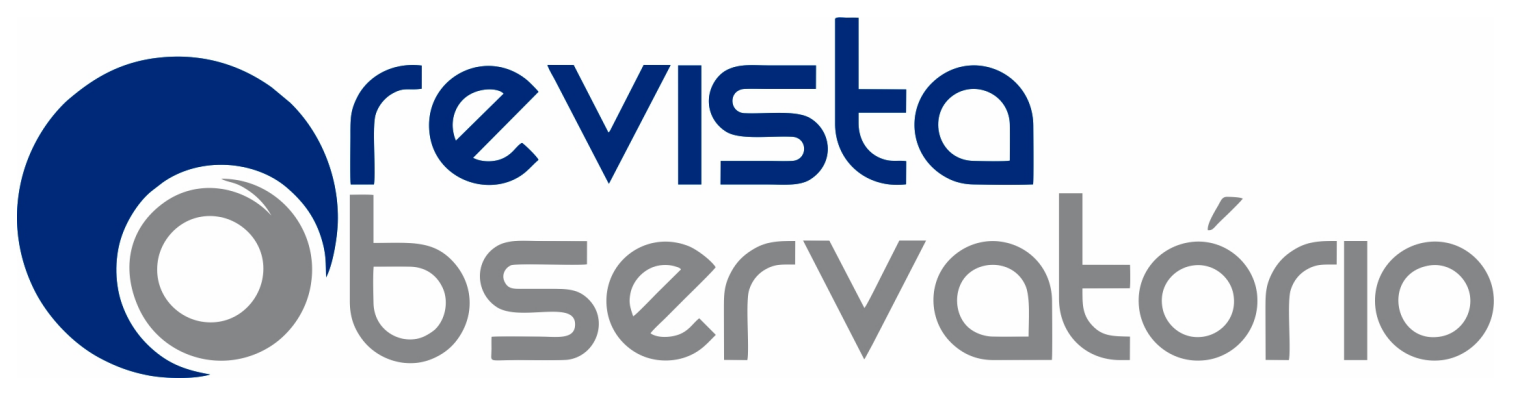

ISSN n² 2447-4266

Vol. 5, n. 6, Outubro-Dezembro. 2019

DOI: http://dx.doi.org/10.20873/uft.2447-4266.2019v5n6p834

realidade. Partindo desse pressuposto, os MADEs utilizados em sala de aula, fariam com que os alunos vivenciassem o processo de aprendizagem partindo da criação, do desenvolvimento e da avaliação dos MADEs, tratando, portanto, de um processo planejado pelo próprio aluno por meio da construção do conhecimento.

Para que ocorra a utilização dos MADEs em uma perspectiva construcionista é preciso que os licenciandos entrem em contato com esse recurso durante a graduação, para que possam pensar métodos de utilizar os materiais autorais, de forma que se adaptem ao conteúdo a ser ministrado e também à turma em que aquele material será apresentado. A disciplina Tecnodocência ministrada na UFC visa trabalhar com esses materiais, buscando a formação dos licenciandos para a utilização das tecnologias digitais em uma perspectiva construcionista (LIMA; LOUREIRO, 2019).

Lima e Loureiro (2019) explicam que a disciplina Tecnodocência traz o professor como aprendiz e parceiro do aluno, onde os dois estão em constante troca de saberes e construindo novos conhecimentos. Na Tecnodocência, o conhecimento prévio do aluno é valorizado, pois através dele o aluno vai atribuir significados aos conteúdos abordados. O aluno é um indivíduo ativo, pois ele é aprendiz, desenvolvedor e produtor do conhecimento.

Partindo da dificuldade dos licenciandos frente à mudança pedagógica e diante desse novo perfil de aluno, o presente artigo propõe responder o seguinte questionamento: quais são as dificuldades que licenciandos enfrentam ao desenvolver Materiais Autorais Digitais Educacionais (MADEs)? Para isso, o objetivo do trabalho é descrever o processo de desenvolvimento de MADEs por estudantes da turma de Tecnodocência do primeiro semestre de 2019. 


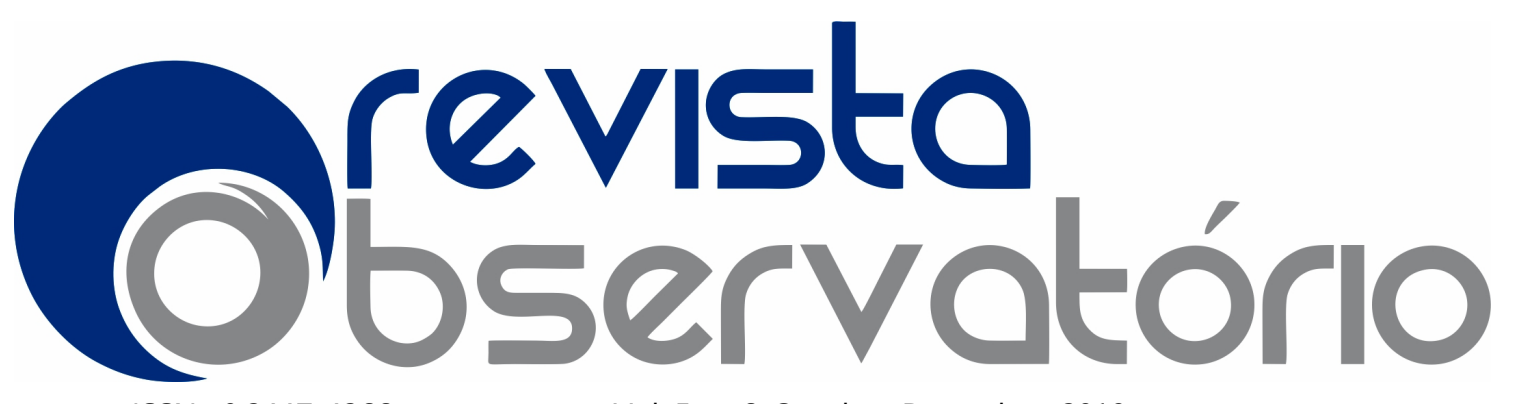

ISSN n² 2447-4266

Vol. 5, n. 6, Outubro-Dezembro. 2019

DOI: http://dx.doi.org/10.20873/uft.2447-4266.2019v5n6p834

\section{Fundamentação Teórica}

O matemático Seymour Papert foi um pesquisador de relevância na área de Inteligência Artificial e o responsável pelo desenvolvimento da proposta construcionista quando vinculada à aprendizagem por meio do computador. Papert (2008), durante sua caminhada acadêmica, buscou evitar que a tecnologia fosse empregada de forma equivocada na educação. Concordando com Piaget que a criança é um ser pensante e construtor de suas estruturas cognitivas e combinado com algumas concepções da inteligência artificial, o matemático buscou em sua teoria meios pelos quais fizessem com que o processo de aprendizagem valorizasse as construções dos sujeitos, embasado pelos seus conhecimentos prévios. Para Papert (2008, p. 158), a tecnologia deveria trazer a máquina "como instrumentos para trabalhar e pensar, como meios de realizar projetos, como fonte de conceitos para pensar novas idéias" e não ser colocada como objeto principal da ação, sendo o único a ser valorizado.

O construcionismo, mesmo baseado na teoria construtivista de Piaget e em suas concepções, contrapõe a noção do abstracionismo do construtivismo e afirma que a aprendizagem acontece por meio da concretude do material produzido pelo sujeito, além de possuírem objetivos distintos. A teoria de Piaget é focada nas habilidades das crianças para atingir etapas educacionais, já a teoria de Papert, além de ser mais ampla, está focada na forma de aprendizagem, observando a interação entre o indivíduo e o objeto. O construcionismo se fundamenta numa perspectiva diversa, onde o indivíduo é encarado como ativo, pois o aluno constrói o seu próprio conhecimento. Nessa concepção, o professor é a ponte para que o aluno possa fazer a construção do conhecimento; não é compreendido como o indivíduo principal do processo, mas como um orientador para a construção desenvolvida pelos alunos. 


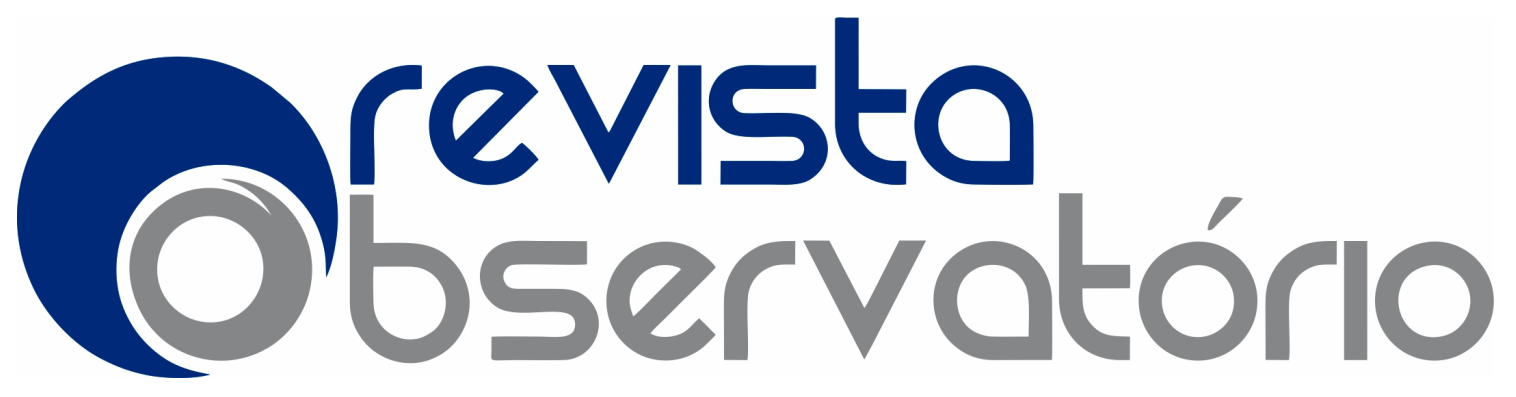

ISSN n² 2447-4266

Vol. 5, n. 6, Outubro-Dezembro. 2019

DOI: http://dx.doi.org/10.20873/uft.2447-4266.2019v5n6p834

Para Valente (1993, p.19), o construcionismo "mostra um outro nível de construção do conhecimento: a construção do conhecimento que acontece quando o aluno elabora um objeto de seu interesse, como uma obra de arte, um relato de experiência ou um programa de computador", ou seja, o aluno é ser ativo da construção.

Na perspectiva educacional, Papert (1986) considera que existem duas filosofias para a utilização das tecnologias, o instrucionismo e o construcionismo. O primeiro, ao contrário do segundo, tem como método de ensino e aprendizagem a transmissão do conhecimento. Nessa concepção, o aluno atua como receptor e o professor como transmissor, não proporcionando ao aluno a construção do conhecimento. No instrucionismo, as atividades se apresentam como um modelo unidirecional, são individuais e não colaborativas.

Como sujeitos ativos da dinâmica educacional, os aprendizes precisam "colocar a mão na massa" (hands-on) no desenvolvimento de suas atividades, em um movimento contrário ao de serem espectadores dos discursos de seus professores. (COSTA; FREITAS, 2010, p. 9).

Os Materiais Autorais Digitais Educacionais (MADEs), segundo Lima e Loureiro (2019), são materiais desenvolvidos pelos professores ou alunos, apoiados no uso das tecnologias digitais e que possuem todo um processo de execução como produto de ensino ou de aprendizagem. Os MADEs perpassam por diversas formas de execução, podendo ser construídos de forma audiovisual, aplicativos on-line e off-line, softwares, entre outros.

Os MADEs surgiram da necessidade de fazer a integração das TDICs com a docência de uma forma que a interdisciplinaridade estivesse presente. Os MADEs, diante de um tema central que não estão vinculados a um conteúdo acadêmico, buscam integrar diversos conhecimentos a serem explicados diante 


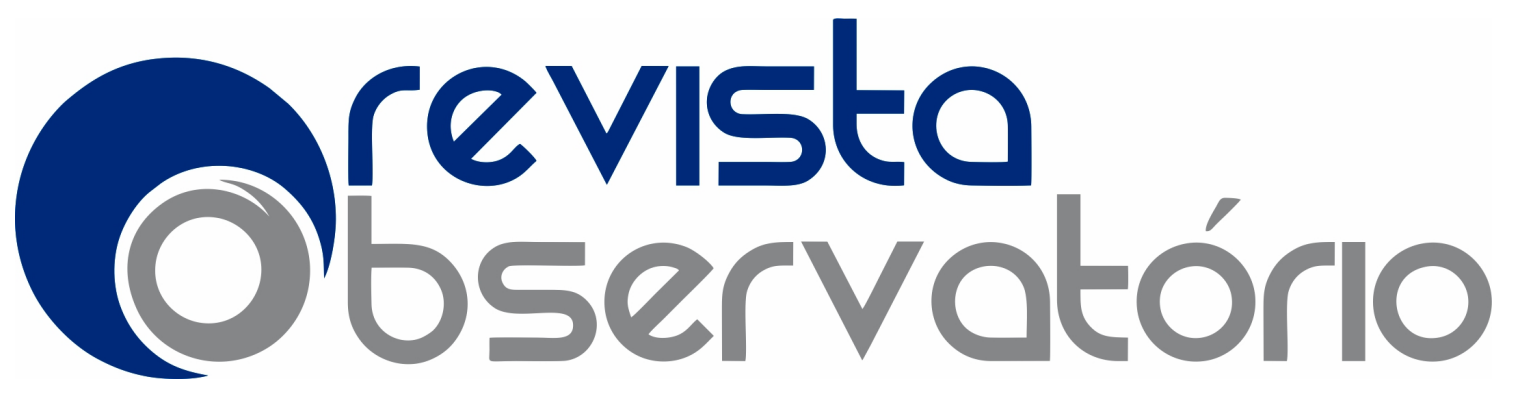

ISSN n² 2447-4266

Vol. 5, n. 6, Outubro-Dezembro. 2019

DOI: http://dx.doi.org/10.20873/uft.2447-4266.2019v5n6p834

do tema escolhido. A perspectiva interdisciplinar seria nesse ponto, a ponte de integração e de intercalação de conteúdos nos MADEs.

Os conteúdos nos MADEs são abordados de uma forma mais homogênea e menos fragmentada. Entram como uma inovação para a educação, no intuito de sair da prática tradicional onde o aluno se apresenta como um ser passivo dentro do processo de aprendizagem, para um processo onde participa como sujeito do processo. Nos MADEs há espaço para o aluno ser instigado a preparar seu próprio material autoral, como forma de aplicação do que foi observado ou desafiado a aprender. O construcionismo presente nos MADEs faz com que os alunos compartilhem conhecimentos tanto entre eles, como com o professor, sendo que todo o trabalho desenvolvido de forma colaborativa se direcione além da produção de um material concreto. Para Papert (2008), o construcionismo acontece por meio do envolvimento do indivíduo com a construção do material, tendo como consequência sua aprendizagem com sentido e significado.

\section{Metodologia}

O presente artigo trata de uma pesquisa exploratória com o objetivo de exemplificar e apresentar um problema específico a fim de conhecê-lo e explorálo (GIL, 2010).

As pesquisas exploratórias têm como propósito proporcionar maior familiaridade com o problema, com vistas a torná-lo mais explícito ou a construir hipóteses. Seu planejamento tende a ser bastante flexível, pois interessa considerar os mais variados aspectos relativos ao fato ou fenômeno estudado. Pode-se afirmar que a maioria das pesquisas realizadas com propósitos acadêmicos, pelo menos num primeiro momento, assume o caráter de pesquisa exploratória. (GIL, 2010, p. 27). 


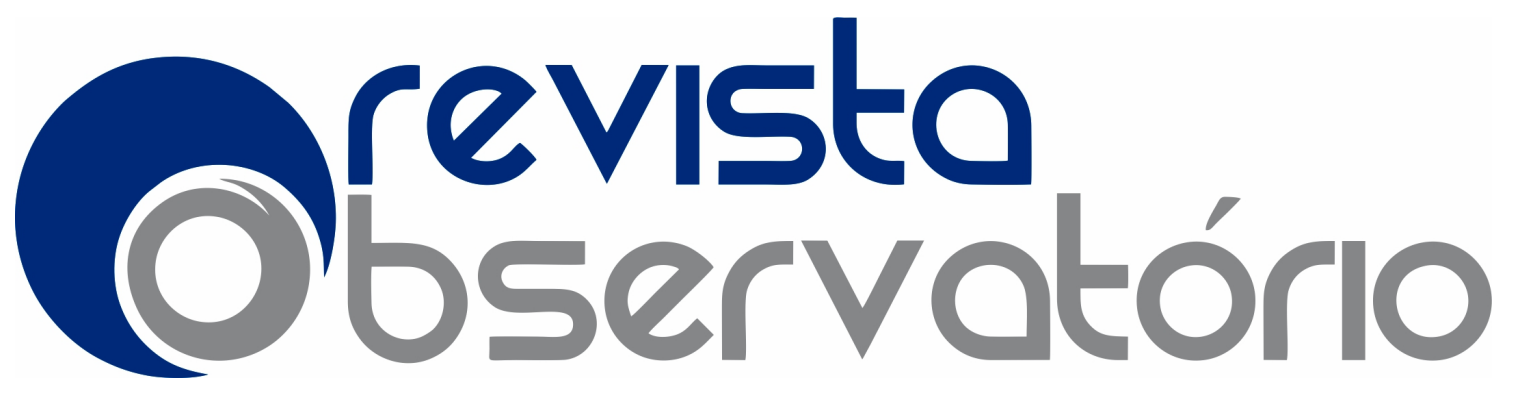

ISSN n² 2447-4266

Vol. 5, n. 6, Outubro-Dezembro. 2019

DOI: http://dx.doi.org/10.20873/uft.2447-4266.2019v5n6p834

A pesquisa tem como público alvo os alunos inscritos na disciplina Tecnodocência do primeiro semestre do ano de 2019 da Universidade Federal do Ceará. Os cursos contemplados na pesquisa foram Biologia, Letras Inglês, Pedagogia, Física, Matemática, Música, Sistemas e Mídias Digitais, e, Química. Dos 28 alunos participantes, 18 são homens e 10 são mulheres. Apresentam faixa etária entre 19 e 33 anos, cursando entre o segundo $\left(2^{\circ}\right)$ e o nono semestre $\left(9^{\circ}\right)$ de suas respectivas graduações na Universidade.

A disciplina Tecnodocência se caracteriza por buscar pela integração entre a docência e as tecnologias digitais, possuindo uma base interdisciplinar ou transdisciplinar entre diversas áreas do saber. A disciplina busca, em uma nova metodologia de ensino, fazer com que o aluno seja o centro da ação para que possa construir seu próprio conhecimento. As aulas ministradas às quintas pela tarde são dialogadas e o aluno, na maior parte das atividades, é orientado a produzir determinadas atividades, que vão desde a esquematização de peças de teatro até a criação dos MADEs (LIMA, 2017).

A pesquisa se subdivide em 3 etapas: planejamento, coleta e análise de dados. No planejamento, foram preparados os instrumentos e os protocolos utilizados na coleta e na análise de dados.

Na coleta, foram desenvolvidos pelos sujeitos da pesquisa os roteiros e os MADEs em 5 grupos heterogêneos, no momento das aulas que ocorreram entre os dias 11 de abril e 25 de abril de 2019, no período da tarde. Os roteiros dos MADEs são compostos pelos seguintes elementos: data, nome dos integrantes de cada grupo, tema interdisciplinar, áreas do saber, descrição da proposta do $M A D E$, equipamentos utilizados para desenvolver o MADE, Recursos Educacionais Digitais utilizados e o passo a passo de como desenvolver o MADE. Os roteiros dos MADES foram desenvolvidos durante as aulas de Tecnodocência em um 


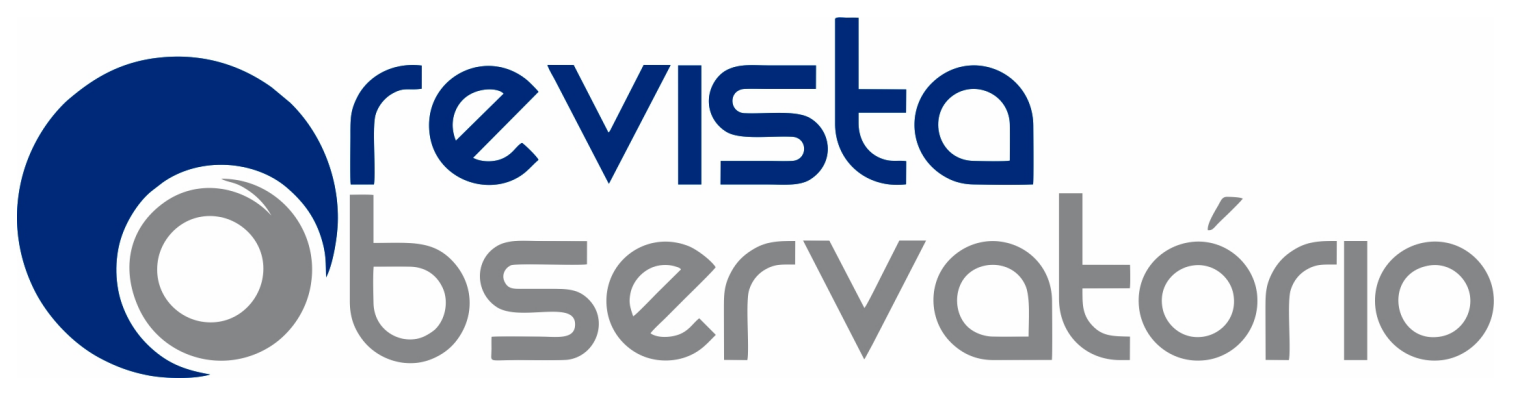

ISSN n² 2447-4266

Vol. 5, n. 6, Outubro-Dezembro. 2019

DOI: http://dx.doi.org/10.20873/uft.2447-4266.2019v5n6p834

arquivo compartilhado no Google Drive para que pudesse ser feito o acompanhamento em tempo real da produção.

$\mathrm{Na}$ análise de dados foi realizada interpretação dos roteiros e dos MADEs, comparada com o referencial teórico utilizado a partir dos seguintes focos: interdisciplinaridade, método de ensino (instrucionista ou construcionista) e inserção de recursos digitais. Para auxiliar no processo foi utilizada a Análise Textual Discursiva que se subdivide em cinco fases: unitarização, categorização, descrição, interpretação e argumentação (MORAES; GALIAZZI, 2011).

\section{Resultados e Discussão}

Foram desenvolvidos um total de cinco (5) MADEs que se caracterizaram como: redes sociais (2), apresentação audiovisual (1), apresentação de slide interativo (1) e livro-jogo (1). A composição dos grupos variou entre 4 e 6 integrantes de áreas diferentes de conhecimento. As produções estão disponíveis na internet no endereço http://profitic.virtual.ufc.br/produto-dos-alunostecnodocencia-2019-1/.

O G1, composto por cinco (5) integrantes dos cursos de Biologia, Pedagogia, Química, Sistemas e Mídias Digitais e Música, abordaram o tema "Planeta Azul". A proposta do MADE é a "transmissão de um podcast chamado 'Planeta de Cores' que lança a notícia sobre o descobrimento de rochas musicais coloridas que provocam emoções nos visitantes, no Planeta Azul" (G1). O grupo elencou apenas três conteúdos vinculados à Psicologia das Cores (Sistemas e Mídias Digitais), Pré-História (Pedagogia), História da Música (Música). Como em um programa de rádio, foram apresentadas notícias fictícias, desenvolvidas entrevistas ressaltando dados científicos. Primeiramente, escolheram as características do planeta, que possuía rochas coloridas e musicais com a 


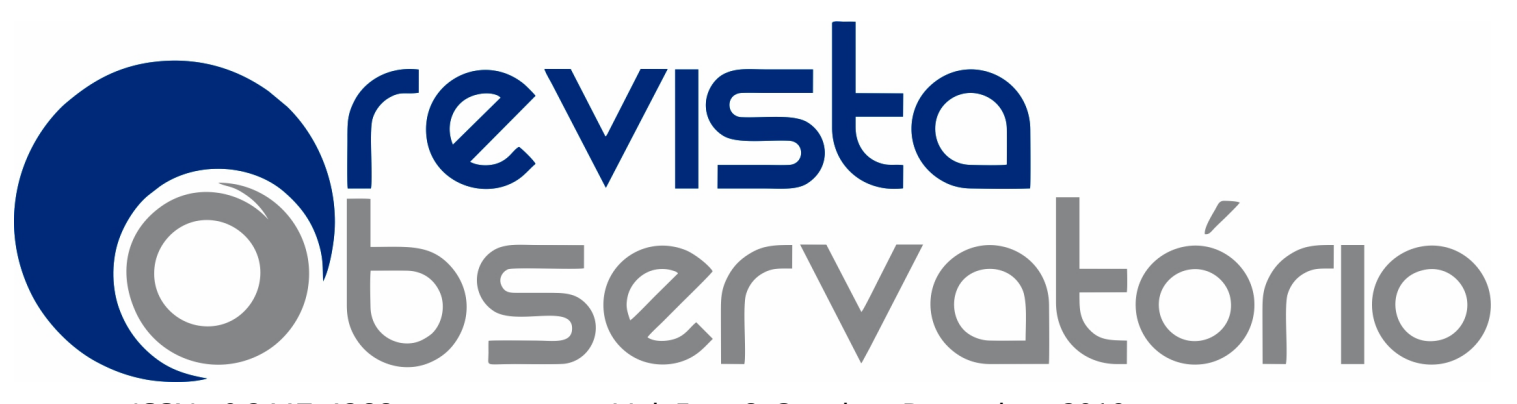

ISSN n² 2447-4266

Vol. 5, n. 6, Outubro-Dezembro. 2019

DOI: http://dx.doi.org/10.20873/uft.2447-4266.2019v5n6p834

capacidade de provocar emoções distintas de acordo com sua cor e melodia. Criaram personagens para participarem do podcast: um apresentador, um especialista, um entrevistador e um nativo da região. Foi gravado um áudio com os momentos de discussão sobre as rochas do planeta azul, posteriormente editado e feito upload para a plataforma SoundCloud.

O G2, composto por quatro (4) integrantes dos cursos de Biologia, Pedagogia, Química e Música abordaram o tema "Folclore Brasileiro" através da apresentação de um vídeo que mostra a relação entre os conteúdos das diferentes áreas, considerando-se, sobretudo, a Festa Junina. O grupo elencou apenas três conteúdos de Educação Ambiental (Biologia), Socialização e Identidade Cultural (Sociologia), e, Etnomusicologia (Música). O vídeo utilizou colagens de Recursos Educacionais Digitais (REDs) como imagens, vídeos e músicas com narração, trazendo música regional nordestina (melodia, harmonia, ritmo, identidade) e fazendo relação direta das interações sociais e emocionais das pessoas. O vídeo foi renderizado e feito upload para o YouTube.

O G3, composto por seis (6) integrantes dos cursos de Biologia, Letras Inglês, Pedagogia, Química e dois alunos do curso de Sistemas e Mídias Digitais, abordou através de uma conta no Instagram (@tecnomusic) o tema Música, partindo dos conteúdos de Fisiologia Humana (Biologia), da Corrosão (Química), dos Algoritmos Computacionais (Sistemas e Mídias Digitais), da Interface Gráfica (Sistemas e Mídias Digitais) e da Paródia (Pedagogia), com o "objetivo de aprimorar o feedback entre aluno e professor e entre os próprios alunos, por meio da rede social, ao mesmo tempo em que os alunos aprendem sobre a temática e apresentam propostas ou alterações a partir das postagens apresentadas" (G3). O grupo primeiramente escolheu e organizou as imagens, vídeos e os textos utilizados e por último publicou os Stories na conta do 


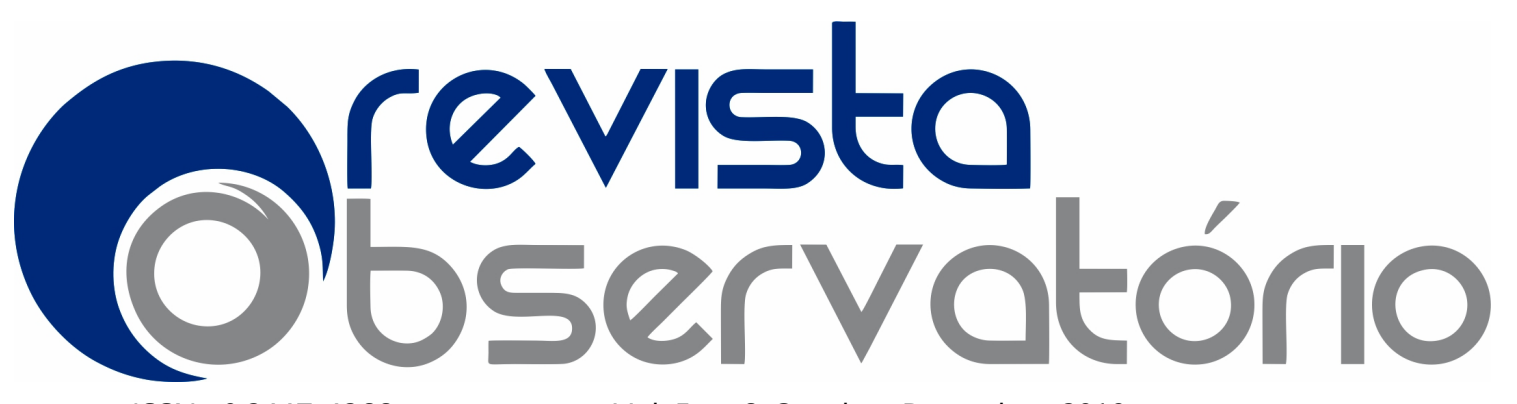

ISSN n² 2447-4266

Vol. 5, n. 6, Outubro-Dezembro. 2019

DOI: http://dx.doi.org/10.20873/uft.2447-4266.2019v5n6p834

Instagram criada pelo próprio grupo para que usuários pudessem ter acesso posteriormente. É importante ressaltar que o grupo preparou atividades juntando as disciplinas duas a duas para que os usuários pudessem realizá-las em momento posterior.

O G4, composto por quatro (4) integrantes dos cursos de Biologia, Física, Matemática e Sistemas e Mídias Digitais, apresentaram o tema "Dança em Dupla" através de uma apresentação de slides interativos. O grupo elencou conteúdos pertencentes ao Design Gráfico (Sistemas e Mídias Digitais), aos Hormônios (Biologia), às Figuras Geométricas (Matemática) e à Força (Física). Foram utilizados pesquisas, imagens e vídeos para a construção da apresentação. Primeiramente escolheram as danças a serem trabalhadas: o tango, o forró, a dança contemporânea e o zouk. Criou-se uma colagem dos recursos selecionados e dos campos para a participação de futuros alunos na plataforma em nuvem Apresentações Google, com o intuito de fazer as relações dos conteúdos pertencentes aos quatro (4) conteúdos elencados.

O G5, composto por quatro (4) integrantes dos cursos de Biologia, Letras Inglês, Física e Sistemas e Mídias Digitais, abordaram o tema "Senhor dos Anéis", partiu de um livro-jogo que "através do uso de uma narrativa interativa, cujos eventos principais já estarão expostos, mas os detalhes e a forma do desenrolar da história são criados pelo aluno." (G5). Explicou os conteúdos de Fisiologia (Biologia), Art Nouveau (Sistemas e Mídias Digitais), Queda Livre (Física) e Tradução Intersemiótica (Letras Inglês). O grupo escolheu os elementos da narrativa e as formas de inserção de informações a ser realizada por futuros alunos. Programaram na plataforma on-line do Twine (twinery.org) a ordenação da narrativa, exportando, posteriormente, o arquivo para o formato HTML. 


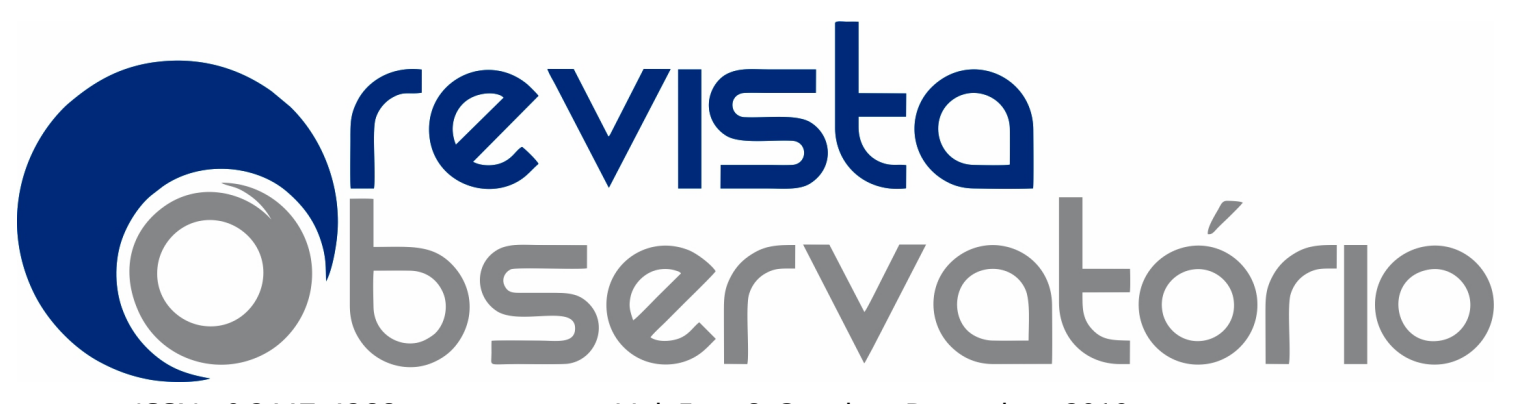

ISSN n² 2447-4266

Vol. 5, n. 6, Outubro-Dezembro. 2019

DOI: http://dx.doi.org/10.20873/uft.2447-4266.2019v5n6p834

Em relação ao foco interdisciplinaridade, que trata da integração entre duas ou mais áreas do saber diante de um tema pré-estabelecido, os conteúdos não aparecem de forma isolada, mas sim em interação entre eles dentro de um mesmo grupo. Alguns grupos fizeram a relação entre duas ou mais áreas do saber (G3); em outros grupos, os conteúdos estavam presentes no roteiro, mas não foram utilizados no desenvolvimento dos MADEs (G1 e G2). O não uso dos conceitos dessas áreas do saber pode ter ocorrido devido à dificuldade de relacionar os conteúdos de algumas áreas do conhecimento com o tema. Em outros casos, o conteúdo estava presente, mas foi abordado de forma isolada e consequentemente não caracterizando o MADE como interdisciplinar (G4 e G5).

O G3 conseguiu diante do tema "Música" e da aplicação na rede social Instagram fazer a integração das diferentes áreas de saber do grupo. No roteiro, as áreas de Biologia, Química, Sistemas e Mídias Digitais e Pedagogia fizeram relação de duas em duas. Em uma das atividades propostas no Instagram @tecnomusic foi perceptível estabelecer a relação entre a corrosão (Química) e o Design Gráfico (Sistemas e Mídias Digitais), devido à explicação do processo de corrosão das cordas do violão por meio da interface gráfica de um aplicativo, que sugere a verificação das condições das cordas do instrumento e o procedimento utilizado para retardar seu desgaste. A interdisciplinaridade também esteve presente no MADE desse grupo por meio da relação da Paródia (Pedagogia) com a Fisiologia do Aparelho Auditivo Humano (Biologia). Foi explicado o conteúdo de fisiologia do ouvido dentro da estrutura da paródia desenvolvida na atividade proposta, que teve como base a música "Romance com Safadeza" dos cantores Wesley Safadão e Anitta. A paródia também foi apresentada como desafio a ser desenvolvido pelos alunos: uma paródia que retratasse os sentidos do corpo humano. 


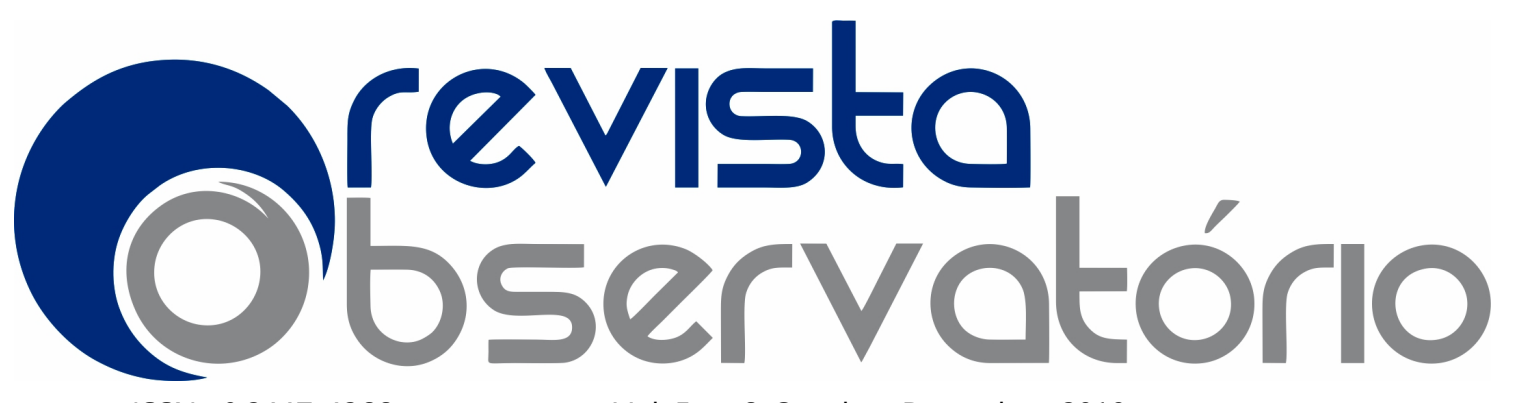

ISSN n² 2447-4266

Vol. 5, n. 6, Outubro-Dezembro. 2019

DOI: http://dx.doi.org/10.20873/uft.2447-4266.2019v5n6p834

O G1 e o G2 trouxeram a interdisciplinaridade de forma parcial, pois uma das áreas não se integrou com a outra e foi apresentada de forma isolada. O G1, ao falar das características das rochas presentes no "planeta azul" integra a história da Música e a Psicologia das cores, pois de acordo com o timbre e as cores emitidas pelas rochas, emoções distintas eram trazidas para os indivíduos. A Pré-história durante o desenvolvimento do MADE não foi elencada com nenhum outro conteúdo de área distinta da Pedagogia, pois apenas esta abordou o hábito histórico dos seres humanos cultuarem objetos, transformando-o em um costume enraizado.

O G2 produziu um MADE audiovisual que possuía como tema o "Folclore brasileiro". Durante a apresentação do vídeo foi perceptível a relação da História da Música e suas interferências na divisão social dos indivíduos (tribos), conteúdo que fez relação com a busca por identidade e socialização vinculado à Pedagogia. O conteúdo de Educação Ambiental (Biologia) foi apresentado no fim do vídeo e de forma isolada, fazendo apenas uma explicação do que condiz ao seu conteúdo.

Os grupos G4 e G5 não desenvolveram MADEs interdisciplinares, pois os conteúdos descritos no roteiro a serem trabalhados não estavam interligados, apareciam de forma isolada. No MADE do G4 os conteúdos estavam divididos e visíveis, pois cada área do saber estava em um espaço específico no MADE, deixando claro os conteúdos a serem trabalhados em suas individualidades. Já no MADE do G5, devido à esquematização da narrativa, os conteúdos estavam ocultos, tornando difícil até o entendimento e o reconhecimento do conteúdo trabalhado.

A interdisciplinaridade vem, na última década, movimentando as discussões educacionais, porém sua implementação passa por dificuldades e 


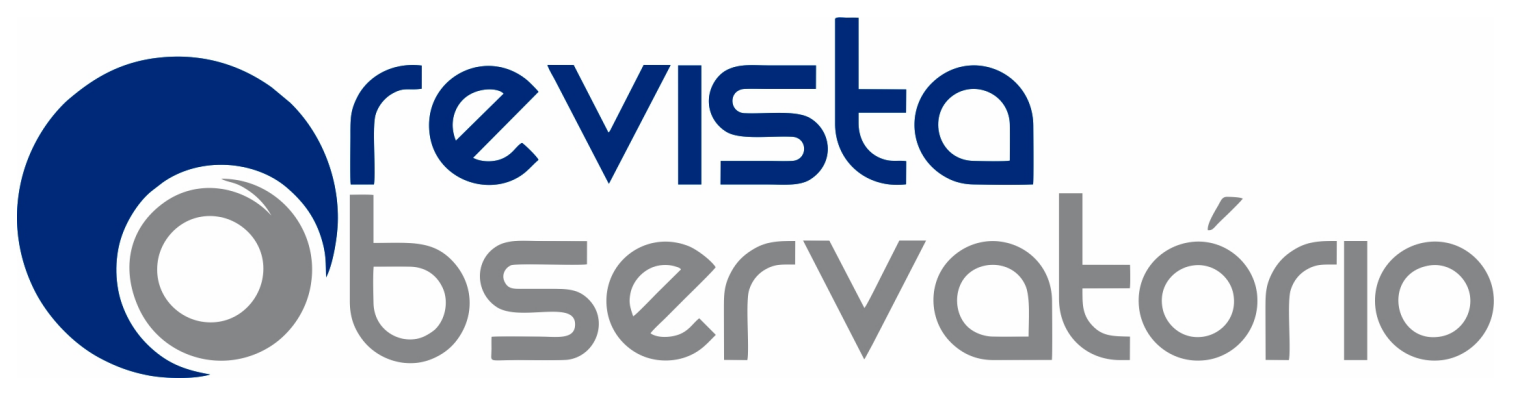

ISSN n² 2447-4266

Vol. 5, n. 6, Outubro-Dezembro. 2019

DOI: http://dx.doi.org/10.20873/uft.2447-4266.2019v5n6p834

desafios. Para Morin (2010), a maior dificuldade está no grande tempo da hegemonia da perspectiva separatista. Diversas gerações de educadores estudaram dentro dessa perspectiva e a tomam como exemplo para a formação dos alunos, tornando-se difícil a mudança de perspectiva. A noção separatista ultrapassa os muros da escola e se cristaliza na academia, pois a cada dia forma mais especialistas. A dificuldade apresentada pode ser um dos motivos pelo qual os grupos G4 e G5 não conseguiram integrar suas áreas específicas dentro do grupo. A interdisciplinaridade para Fazenda (2002) é uma troca recíproca de conhecimentos que vai gerar o enriquecimento tanto dos alunos, quanto dos professores que estão trabalhando em conjunto.

Independente das dificuldades, alguns movimentos educacionais estão buscando a implementação de novas metodologias, saindo do tradicionalismo. $\mathrm{Na}$ academia e nas escolas, professores já trabalham com essa perspectiva, pois os Parâmetros Curriculares Nacionais da Educação (BRASIL, 1999) suscitam a interdisciplinaridade como elemento fundamental para os mecanismos de ensino.

A interdisciplinaridade integra as disciplinas a partir da compreensão das múltiplas causas ou fatores que intervêm sobre a realidade e trabalha todas as linguagens necessárias para a constituição de conhecimentos, comunicação e negociação de significados e registro sistemático dos resultados. (BRASIL, 1999, p. 89).

Partindo da busca pela inserção da interdisciplinaridade na educação, acredita-se ser mais fácil a utilização dessa perspectiva por licenciandos que já tiveram contato com a interdisciplinaridade em suas práticas docentes, motivo pelo qual supõe-se que os grupos $G 1$, G2 e G3 tenham conseguido de forma total ou parcial fazer a interdisciplinaridade acontecer nos MADEs desenvolvidos. 


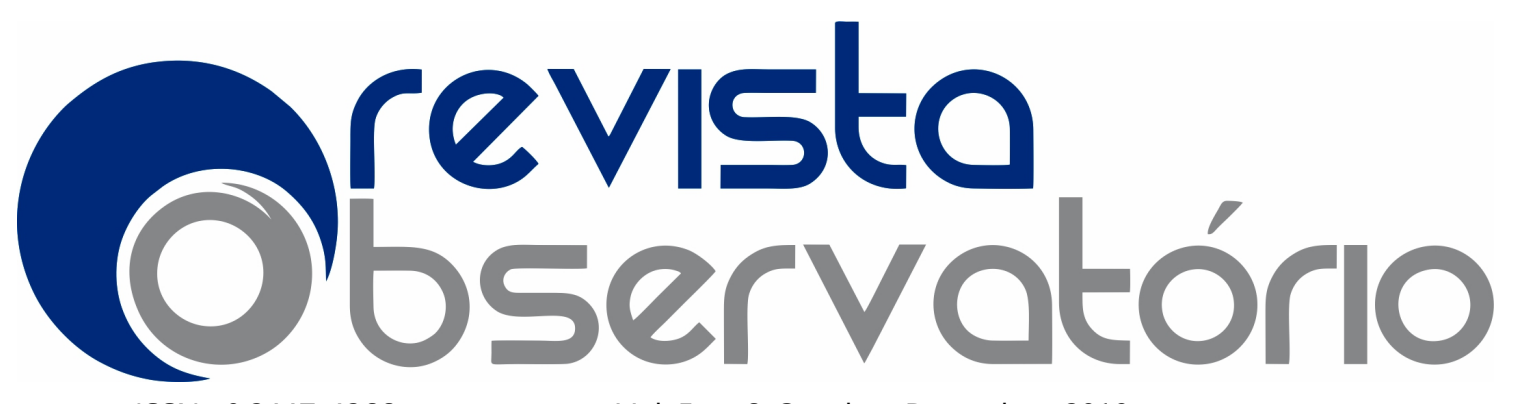

ISSN n² 2447-4266

Vol. 5, n. 6, Outubro-Dezembro. 2019

DOI: http://dx.doi.org/10.20873/uft.2447-4266.2019v5n6p834

Em relação foco método de ensino foram observados nos MADEs e em seus roteiros duas propostas, o construcionismo que busca a produção e interação do aluno, sendo este o centro da ação e o produtor do conhecimento a partir do uso das TDICs, e o instrucionismo que tem como foco a transmissão de conteúdo pelo professor ou pelo dispositivo tecnológico utilizado para o aluno, seguindo apenas as instruções repassadas.

Os cinco (5) grupos trabalharam dentro da proposta construcionista, pois apresentaram um espaço voltado para interação do aluno, para a construção do seu próprio produto e assim formar seu conhecimento sobre determinado assunto. O G1 trouxe a participação do aluno por meio dos comentários na plataforma em que estava sendo reproduzido o podcast, e por meio do desafio de realizar a catalogação dos timbres e cores de acordo com as emoções que emitem, além de apontar os costumes pré-históricos enraizados que pertencem à sociedade na qual estão inseridos.

O G2 trouxe a participação do aluno por meio dos questionamentos durante a execução do vídeo, além de solicitar que realizem uma apresentação musical com o tema "educação ambiental". O G3 apresentou desafios a serem realizados pelos alunos. Foi solicitada a criação de uma paródia diante dos órgãos sensitivos do corpo humano, além da criação de uma interface para prevenir a corrosão das cordas musicais, usando o princípio da visibilidade.

$\mathrm{Na}$ apresentação de Slides Interativos proposta pelo G4, foi solicitado que os alunos inserissem em formato de texto as relações ocorrentes entre os estilos de dança em dupla apresentados e os conteúdos sobre Força, Hormônios, Design Gráfico e Figuras Geométricas, possibilitando a cada grupo a inserção de ideias e conhecimentos que aprofundassem os assuntos a serem estudados. O G5 trouxe a participação do aluno por meio da possibilidade de escolha de caminhos a 


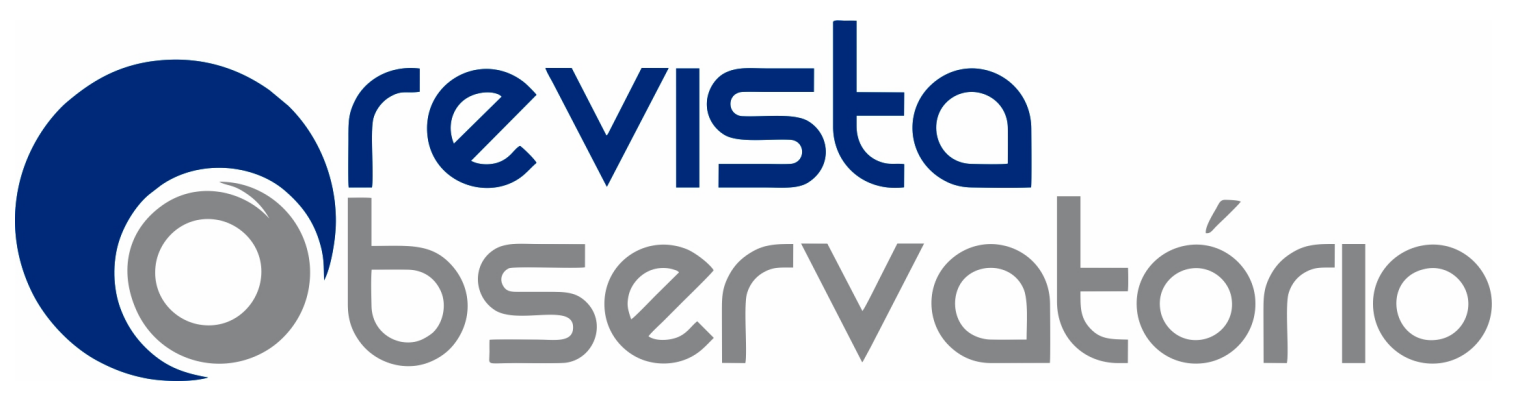

ISSN n² 2447-4266

Vol. 5, n. 6, Outubro-Dezembro. 2019

DOI: http://dx.doi.org/10.20873/uft.2447-4266.2019v5n6p834

serem tomados dentro da narrativa do livro-jogo e por meio da contribuição com a escrita de determinados pontos da história desenvolvida.

Os métodos de ensino vigentes ainda na contemporaneidade perpassam por um modelo secular pautado na construção social e cultural em que o professor é o centro da ação docente e que o aluno está em sala apenas para receber e absorver conteúdos sem ser necessária a ação produtiva, criativa voltada para a construção do conhecimento. Com a renovação da geração de professores e com a utilização de diferentes métodos e estratégias de ensino o problema pode ser solucionado. O construcionismo, proposto por Papert (2008), contribui a esse favor, principalmente considerando-se sua base pautada na construção do conhecimento quando o indivíduo experimenta e desenvolve seus próprios produtos, maximizando a aprendizagem com o mínimo de ensino. $\mathrm{O}$ desenvolvimento de um produto real é realizado partindo da utilização de recursos digitais.

O uso de computadores nas escolas está cada vez mais frequente, com o objetivo de trazer o recurso como auxílio metodológico e aproximando os alunos da reflexão, do pensamento crítico e do conhecimento.

A tecnologia pode apoiar uma mega mudança na educação, tão ampla quanto a que vimos na medicina, porém em um processo diretamente oposto ao que conduziu às mudanças na medicina moderna. A medicina mudou, tornando-se cada vez mais técnica em sua natureza; na educação, a mudança virá pela utilização de meios técnicos para eliminar a natureza técnica da aprendizagem na Escola. (PAPERT, 2008, p. 64).

Com a popularização da tecnologia na educação e, consequentemente, com as necessidades de atuação e experimentação dos alunos, é possível 


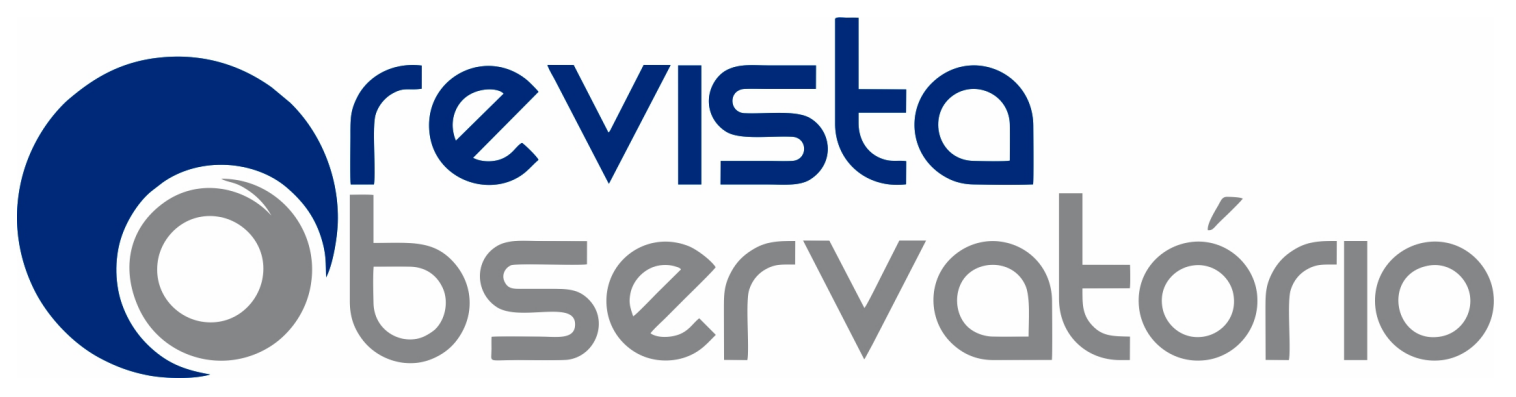

ISSN n² 2447-4266

Vol. 5, n. 6, Outubro-Dezembro. 2019

DOI: $\underline{\text { http://dx.doi.org/10.20873/uft.2447-4266.2019v5n6p834 }}$

perceber nos dados coletados na pesquisa, maior frequência na busca pelo uso de didáticas e metodologias diversificadas. O desenvolvimento dos MADEs denotou uma necessidade de produção do professor com espaços para a produção conjunta do aluno, com uma preocupação latente no processo de aprendizagem do aluno diante do uso das TDICs na docência.

Em relação ao foco recursos digitais utilizados na construção dos MADEs, os cinco (5) grupos tiveram êxito. Os grupos utilizaram tanto tecnologias digitais off-line (softwares de edição) como on-line (redes sociais), além dos equipamentos digitais (notebooks, projetores, microfones, entre outros).

O G1, ao desenvolver O MADE, inserindo na rede social SoundCloud, utilizou os seguintes equipamentos digitais: celular e carregador para gravar o podcast, o software de edição de áudio "Audacity", um notebook com cabo de força e internet, conta aberta no SoundCloud. Possibilitou aos alunos, usuários do MADE, que através de comentários e publicações realizadas no próprio SoundCloud participassem do podcaste criassem materiais educacionais, pois foi requisitado aos alunos que catalogassem as emoções passadas por cada cor e som emitida pelas rochas do planeta azul inserido na narrativa e que também escrevessem costumes pré-históricos que continuam na atualidade dentro da sociedade em que vivem.

O G2 utilizou notebooks, microfones e o software de edição de vídeo MovieMakerpara a realização do MADE. Para a produção do vídeo também foram utilizados como Recursos Digitais vídeos e imagens de quadrilha, festa junina, interações sociais e a lenda do curupira. O grupo solicitou que os alunos criassem uma apresentação musical com a temática de "educação ambiental", possibilitando que os alunos produzissem seus próprios materiais e que utilizassem recursos digitais como o notebook. 


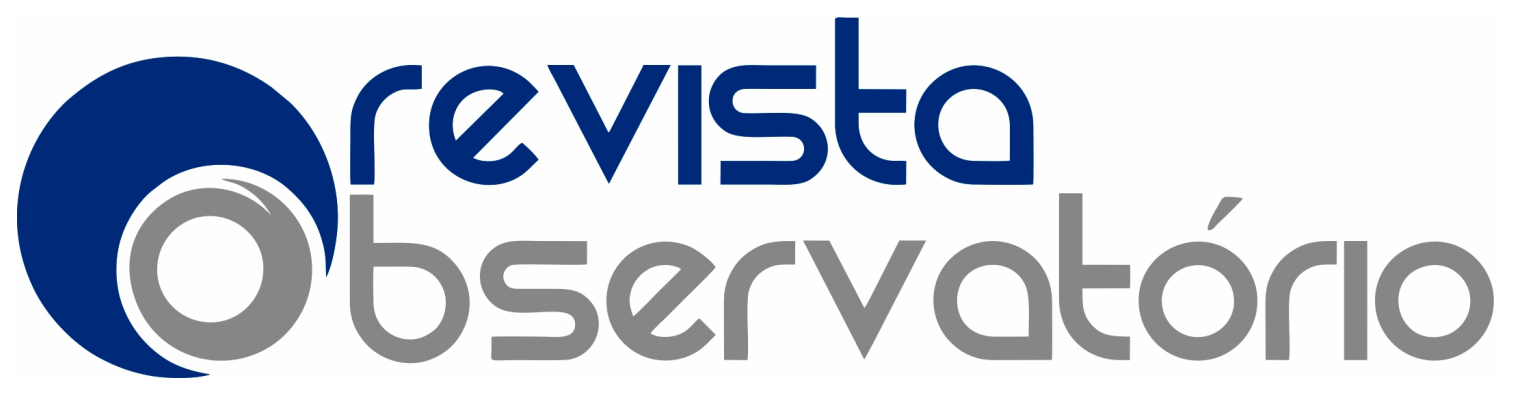

ISSN n² 2447-4266

Vol. 5, n. 6, Outubro-Dezembro. 2019

DOI: http://dx.doi.org/10.20873/uft.2447-4266.2019v5n6p834

O G3, ao desenvolver o MADE na rede social Instagram, utilizou tablets, celular, softwares de edição de vídeo como equipamentos digitais. Como Recursos Digitais utilizaram imagens, músicas e vídeos para discutir os conteúdos (Paródia, Corrosão, Fisiologia, Design e Interface de usuário, e, Algoritmo computacional) propostos no roteiro. Os usuários do MADE utilizaram a própria rede social para participar dos desafios propostos pelo grupo, possibilitando a utilização do celular como equipamento digital off-line e do Instagram como material on-line.

O G4, através de uma apresentação de slides interativos em nuvem, e, portanto, on-line, de temática "dança em dupla" utilizou o notebook e o PowerPoint como ferramenta de apresentação e desenvolvimento do MADE. Os gifs, imagens e vídeos presentes na apresentação interativa foram os Recursos Digitais utilizados pelo grupo. Os alunos tiveram o momento de utilização desses recursos na atividade requerida, onde teriam que escolher um vídeo de dança e fazer as relações dos conteúdos dentro da apresentação interativa apresentada como MADE.

O G5 utilizou a plataforma de programação Twine para o desenvolvimento do livro-jogo, contendo uma narrativa não-linear. Foram utilizados notebook a a plataforma de edição como equipamentos digitais. As imagens apresentadas no jogo fazem parte dos Recursos Digitais utilizados pelo grupo. Para a manipulação do jogo, os alunos precisaram utilizar o notebook como equipamento digital, pois somente com ele os usuários do MADE poderiam contribuir na narrativa e escolher os caminhos a serem seguidos dentro do MADE.

Conforme Pereira e Lopes (2005), a utilização das TDICs no contexto da Docência mobiliza a formação de sujeitos criativos e integrados ao novo que se 


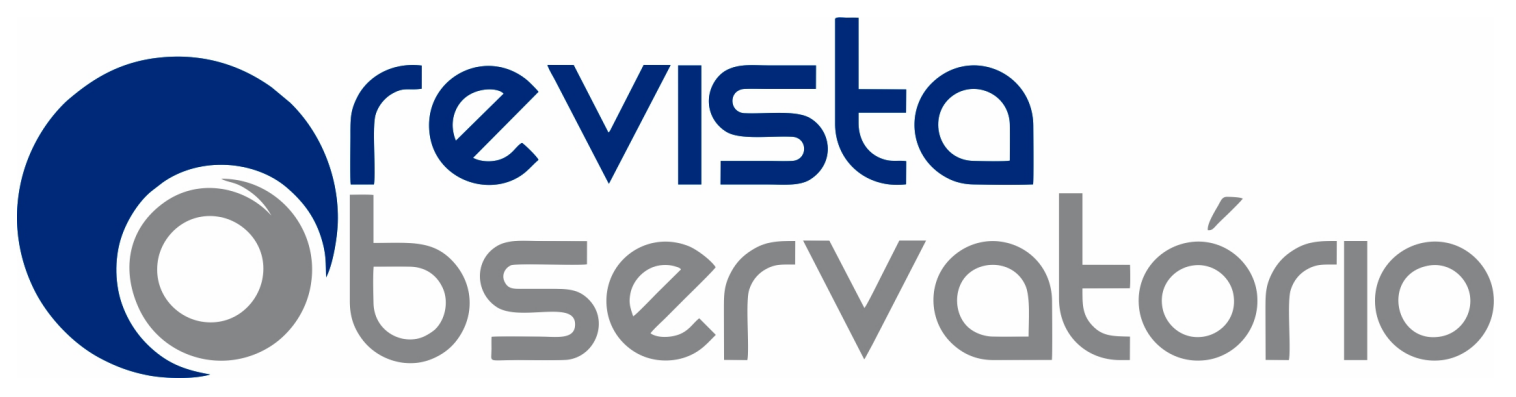

ISSN n² 2447-4266

Vol. 5, n. 6, Outubro-Dezembro. 2019

DOI: $\underline{\text { http://dx.doi.org/10.20873/uft.2447-4266.2019v5n6p834 }}$

processa na sociedade, de maneira crítica e reflexiva, aparecendo como um caminho significativo para o desenvolvimento de mudanças no fazer docente.

A tecnologia combinada com a interdisciplinaridade e dentro da proposta construcionista faz com que, na teoria e na prática, outras experiências docentes ocorram. Sibilia (2012, p. 53) enfatiza que a escola, sob os ditos moldes tradicionais, experiencie um estado de espera por seu "atestado de óbito", percebendo a demanda pelo desenvolvimento de uma formação docente que ultrapasse o modelo estabelecido.

O contato mais presente com as tecnologias digitais ajuda os alunos a terem mais conhecimentos de softwares, aplicativos, dentre outros, denotando um dos motivos pelos quais os alunos dos grupos não tiveram dificuldade em desenvolver os MADEs partindo do uso das tecnologias digitais.

\section{Considerações Finais}

Tendo como objetivo analisar quais são as dificuldades que os licenciandos da disciplina Tecnodocência ofertada no primeiro semestre de 2019 apresentam em relação à utilização dos Materiais Autorais Digitais Educacionais (MADEs), pôde-se perceber que a forma de pensar a prática docente dos participantes se modificou em alguns quesitos. As mudanças trouxeram reflexos significativos para entender como a nova geração de licenciandos pensa e produz.

$\mathrm{Na}$ interpretação realizada a partir do foco utilização dos recursos digitais apresentaram um uso efetivo das TDICs principalmente na execução dos MADEs e durante o planejamento da aula; não tiveram dificuldades em utilizar os recursos digitais. Mostraram ter domínio dos recursos on-line e off-line. Foram utilizados redes sociais e softwares com os mais diversos objetivos relacionando- 


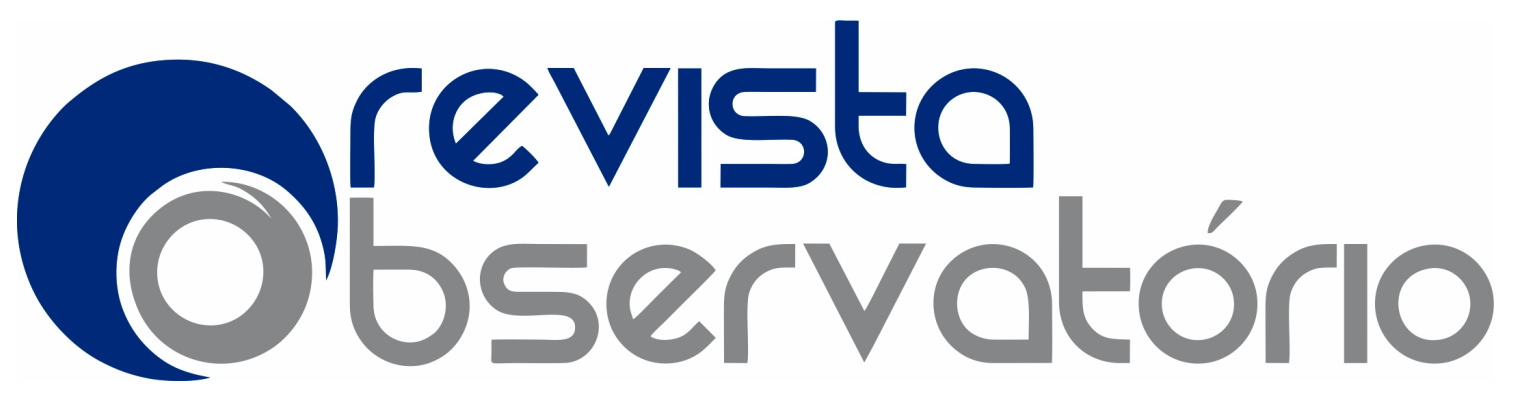

ISSN n² 2447-4266

Vol. 5, n. 6, Outubro-Dezembro. 2019

DOI: http://dx.doi.org/10.20873/uft.2447-4266.2019v5n6p834

se com as novas gerações abordadas por Ceretta e Froemming (2011), gerações que estão em contato com a tecnologia e que buscam trazer os recursos do seu cotidiano para a utilização profissional, no caso de licenciandos no âmbito educacional.

Em relação ao foco método de ensino, percebeu-se que os alunos buscaram trazer o aluno para o centro da ação, seja através da produção de determinados materiais ou através da captação de seus conhecimentos prévios, valorizando suas experiências. Os alunos da disciplina Tecnodocência, partindo das interpretações dos quesitos apontados na metodologia, não tiveram problemas em fazer o usuário dos MADEs como produtores do seu próprio conhecimento através das experiências que tiveram em sala de aula. $O$ construcionismo de Papert (2008) foi aplicado nos planos e nos MADEs, demonstrando uma quebra da ideia tradicional que vem a muito tempo trazendo professor e conteúdo como o centro da ação.

Em relação ao foco interdisciplinaridade constatou-se que, mesmo com a busca por inovação na educação, os reflexos das especializações e da individualidade apresentados pela história educacional, mostrou-se perceptível na dificuldade de relacionar os conteúdos.

Os dados recolhidos diante da disciplina Tecnodocência ofertada no primeiro semestre de 2019 serão apresentados aos coordenadores da disciplina como fonte de estudo em relação ao uso de tecnologia na educação e a relação do licenciando e dos discentes com os MADEs.

A área educacional passa e ainda passará por diversas transformações e os quesitos interpretados trouxeram recursos para novos "olhares" sobre a relação licenciando, as tecnologias e sua formação. Este trabalho debateu a 


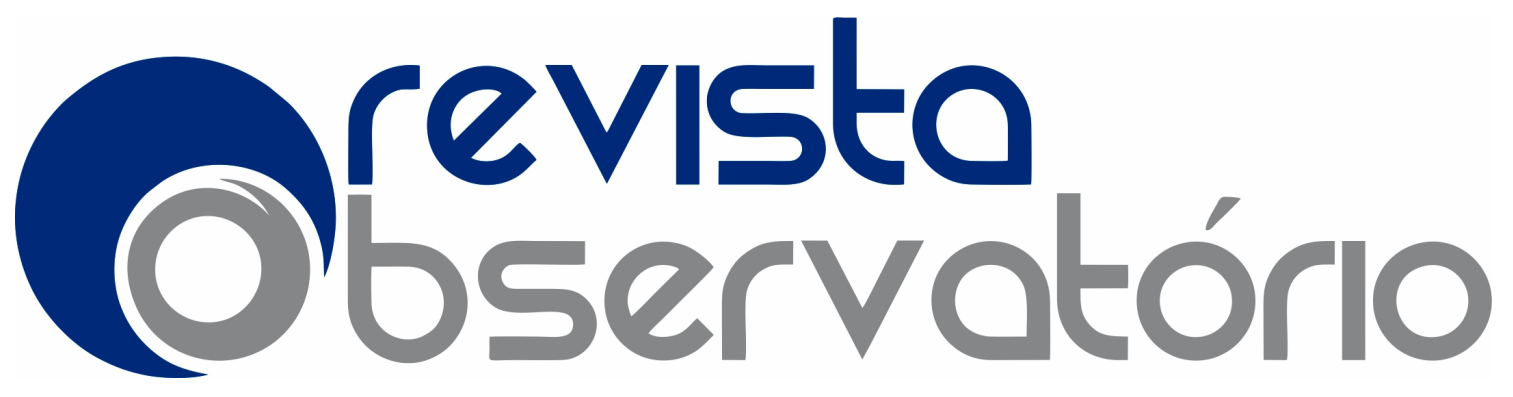

ISSN n² 2447-4266

Vol. 5, n. 6, Outubro-Dezembro. 2019

DOI: $\underline{\text { http://dx.doi.org/10.20873/uft.2447-4266.2019v5n6p834 }}$

interpretação apenas de aspectos relacionados a uma única disciplina e a um determinado grupo, faz-se, portanto, necessário ampliar o escopo de estudos para uma compreensão melhor do problema. Em uma continuação à busca por dados em materiais como o Plano de Aula e a própria Prática Docente podem desencadear novas respostas sobre a dificuldade do licenciando em meio ao uso de MADEs na docência.

\section{Referências}

BRASIL. Ministério da Educação. Secretaria de Educação Média e Tecnológica. Parâmetros Curriculares Nacionais: Ensino Médio. Brasília: Ministério da Educação, 1999.

CERETTA, S. B.; FROEMMING, L. M. Geração Z: compreendendo os hábitos de consumo da geração emergente. Revista Eletrônica do Mestrado Profissional em Administração da Faculdade de Potiguar, Universidade Potiguar, Mossoró - RN, $n^{\circ} 2,2011$.

COSTA, R. S.; FREITAS, H. A Influência da Confiança do Decisor no Risco Percebido e no Comportamento de Compra de Tecnologia da Informação: Proposição de um Modelo. In: CONGRESSO INTERNACIONAL DE GESTÃO DE TECNOLOGIA E SISTEMAS DE INFORMAÇÃO, 7, 2010, São Paulo. Anais do $7^{\circ}$ CONTECSI, 2010. p. $1-21$.

FAZENDA, I. C. A. Interdisciplinaridade: história, teoria e pesquisa. Campinas:

Papirus, 2002.

FREIRE, P. Pedagogia da Autonomia: saberes necessários à prática educativa. São Paulo: Paz e Terra, 1996.

GIL, A. C. Como elaborar projetos de pesquisa. São Paulo: Atlas, 2010. 


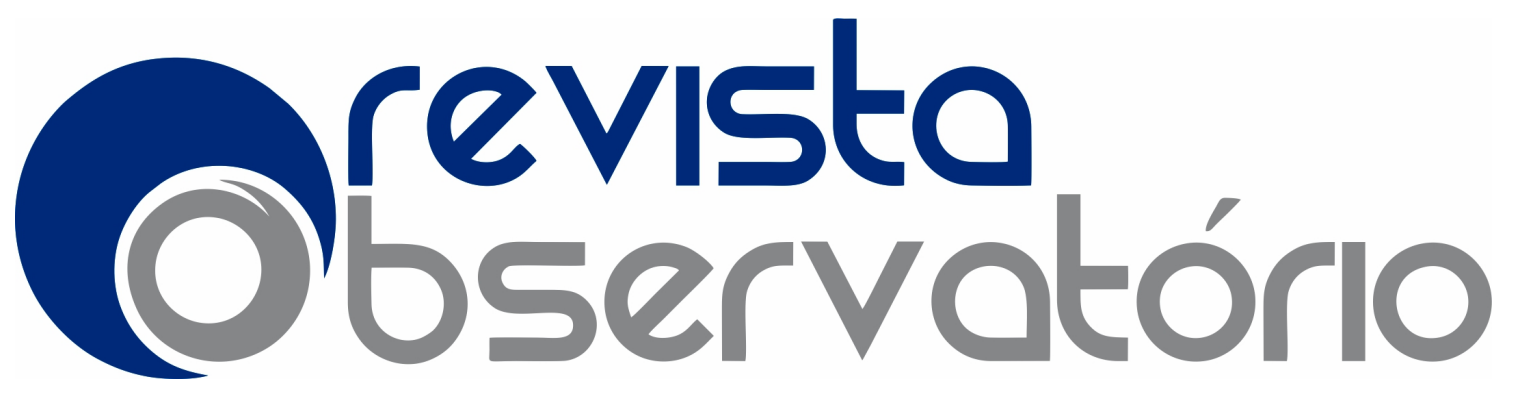

ISSN n² 2447-4266

Vol. 5, n. 6, Outubro-Dezembro. 2019

DOI: $\underline{\text { http://dx.doi.org/10.20873/uft.2447-4266.2019v5n6p834 }}$

LIMA, L. de. Tecnodocência: integração entre tecnologias digitais e docência na formação de licenciandos. In: Fundação Carlos Chagas. Prêmio Rubens Murillo Marques 2017: Experiências docentes em licenciaturas. São Paulo: FCC, 2017, p. 105-132.

LIMA, L. de; LOUREIRO, R. C. Tecnodocência: concepções teóricas. Fortaleza: Edições UFC, 2019.

MASETTO, M. T.; BEHRENS, M. Novas tecnologias e mediação pedagógica. São Paulo: Papirus, 2000.

MORAES, R.; GALIAZZI, M. do C. Análise Textual Discursiva. ljuí: Ed. Unijuí, 2011. MORIN, E. Os sete saberes necessários à educação do futuro. São Paulo: Cortez, 2010.

PAPERT, S. A Máquina das Crianças: repensando a escola na era da informática. Porto Alegre: Artmed, 2008.

PAPERT, S. LOGO: Computadores e Educação. São Paulo: Brasiliense, 1986.

PEREIRA, A. R.; LOPES, R. de D. Legal: Ambiente de Autoria para Educação Infantil apoiada em Meios Eletrônicos Interativos. In: SIMPÓSIO BRASILEIRO DE INFORMÁTICA NA EDUCAÇÃO, 16, 2005, São Paulo. Anais do SVI SBIE, 2005. p. 1-8.

SIBILIA, P. Redes ou paredes: a escola em tempos de dispersão. Rio de Janeiro: Contraponto, 2012.

VALENTE, J. A. Diferentes Usos do Computador na Educação. In: VALENTE, J. A. (Org.). Computadores e Conhecimento: repensando a educação. Campinas, SP: Gráfica da UNICAMP, 1993, p.1-23. 